\title{
MODERN METHODS IN THE STUDY OF FOSSILS.
}

\author{
By A. SMITH WOODWARD, LL.D., F.R.S. \\ (Presidential Address delivered February 3rd, 1905.)
}

\footnotetext{
$\mathrm{O}^{\mathrm{N}}$
} $\mathrm{NE}$ of the most conspicuous features of the Geologists' Association has always been the catholicity of its interests. From the speculations of the Nebular Hypothesis to the phenomena of earthquakes and volcanoes; from the study of deep-sea dredgings to that of metamorphic rocks; from the optical properties of a crystal to the evolution of a mammal or even of man himself-all subjects of scientific inquiry have fallen within the scope of our proceedings. This wide sympathy with the progress of the natural sciences has, indeed, been one of the main factors in the continual success of the Association. The majority of our members are well occupied with other vocations besides the pursuit of pure science, and have only the hours of recreation to devote to geological studies. The wider the scope and the more general the nature of the questions discussed at our meetings, the more thoroughly, therefore, are they appreciated.

When the Association was founded, nearly half a century ago, it was much easier to deal with the latest results of geological research in general terms than it is in these later days of extreme specialisation. In fact, the opinion has sometimes been expressed, that it is no longer possible for the amateur, with restricted leisure, to do much towards the progress of scientific discovery. I venture to think, however, that, so far as the past history of the earth is concerned, there is still ample scope for casual work of the highest value. The collector of fossils, in any case, even if he be confined to one small district, is just as important now as he ever was for the progress of Palæontology. The only difference is that, whereas in former days his chief interest centred in filling a cabinet with choice specimens, his present aim should be rather to illustrate certain definite problems and principles which modern research has formulated. At the time when Parkinson's "Organic Remains" was a drawing-room book, and when Mantell could secure no less than 130 personal subscribers for his "Geology of the South-east of England," fossils excited interest as objects of curious wonder; in later days they have gradually become familiar even to the uninitiated, and the pleasure experienced in collecting them depends on their connection with certain theories of life and change which have a bearing on some of the most fundamental problems of Natural Philosophy. 
It is true that in some respects the study of fossils has gradually been beset with repellent difficulties, which it is not always easy to ignore. There are, indeed, three circumstances which seriously hinder a beginner, and are detrimental to the progress even of an expert student.

In the first place, the advances made by research have led to the discovery of many mistakes in the original naming of genera and species on the evidence of imperfect specimens; while they have also proved that in some cases different parts of one and the same animal or plant have received two or more distinct names. All these corrections have to be remembered when consulting the books and papers which deal with the fossils in question. It is thus necessary to be familiar with the entire history of their discovery.

Secondly, the so-called "law of priority" in nomenclature has caused too many mere literary critics to invade scientific journalism with long disquisitions on matters concerning which they are incompetent to form a judgment; while, still worse, the glamour of easily-earned glory which the aforesaid "law" promises to an industrious reader, has diverted from scientific work not a few talents which began well and might have done real service in the advancement of research. It still has to be recognised that generic and specific names (which are simply instruments for convenience) evolve to an exact meaning just as organisms evolve to produce fixity in their parts in a favourable environment. It also bas to be generally realised that the only nomenclature of genuine use is that actually employed in scientific memoirs, and not that of mere lists which are prepared as literary exercises. The result is, that since the fatuous fad of retrospective "priority" became fashionable, the naming of certain groups of fossils has lapsed into inextricable confusion; and until common-sense methods prevail a serious obstacle is opposed to real scientific work."

Finally, it must be admitted that most of the books which a beginner has to consult are too much in the nature of dictionaries, and give too little prominence to the statement of problems and general principles. The accumulation of endless new facts, is, of course, essential to all progress; but the only sensible advances in science are made when known facts are correlated in the light of new discoveries. In the present state of Palæontology, I am only acquainted with one general elementary treatise which deals with the whole subject and is helpful from this point of view. I refer to Prof. H. S. Williams's little work on "Geological Biology," published in New York in 1895 (Henry Holt \& Co.), which seems to be scarcely known among students in this country.

"For an illustration of the impossibility of applying the "law of priority" to Conchology, see A.J. Jukes-Browne, "On some Questions of Nomenclature," Journ. Conchology, vol, ii (1904), pp. 97-103. 
For much service to Palæontology, however, deep reading is far from essential, and no casual contributors are doing more valuable work than those who let it be known in their own neighbourhood that they are interested in fossils. Their houses become the receiving offices, so to speak, to which all accidental discoveries are brought; and they are thus the means of preserving from destruction many unique specimens which would otherwise be lost. Only quite lately the finest Labyrinthodont skull hitherto discovered in Britain-one of the most important Triassic skulls ever found-was rescued solely because the Stanton quarrymen knew that the Rev. F. F. Key was interested in fossils and might be glad to see "a calf's head in stone" (as they described it) before it was broken up. In fact, a large proportion of the known extinct animals are only represented by one or two specimens obtained in this accidental manner; and when we remember how sporadic is the distribution of fossils in many rocks, we can appreciate the importance of spreading over the kingdom a body of amateurs, such as those who form the greater part of our Association.

In this connection I also wish to emphasise the scientific value of collections of mammal-bones carefully made from superficial deposits, especially from those of known historic date. In our country very little attention has hitherto been devoted to the domestic animals which accompanied man at different times during the many centuries which have elapsed since history began in this part of Europe. Two of our members, Dr. Frank Corner and Mr. A. Santer Kennard, have already made much progress in obtaining materials for such a study from the neighbourhood of London; and some of us remember the interesting series of skulls of sheep, of various known dates, exhibited by Mr. Kennard at our last Conversazione. We need large collections of bones from all the old centres of population; for when they are sufficiently extensive they will prove interesting not only from our point of view, but also from that of the historian who is dealing with trade routes and migrations.

The collector of fossils greatly enhances the value of his contributions to Palæontology as soon as he begins to devise methods of preparing them for satisfactory study. Some of our most striking modern advances, indeed, have only been made possible by improvements in the art of extracting fossils from the matrix. It is long since Mantell began pioneer work of this kind and astonished the audiences at his lectures with the fossil fishes which he had laboriously divested of enveloping chalk by means of small knives and needles. It is also long since he pieced together and chiselled out the bones of Dinosaurs from the Wealden Sandstone and Kentish Rag. The methods he adopted have been successfully employed by many subsequent workers, until now we have reached the refinement of cleaning fossils 
by machinery. Some years ago Mr. B. Stürtz, of Bonn, and Dr. C. E. Beecher, of New Haven, devised a means of treating pyritised fossils in hard rock with metal brushes, and achieved remarkable success in cleaning the most minute structures of starfishes and trilobites. Our member, Mr. Upfield Green, has done well in applying the same method to pyritised fossils from the Devonian slates of Cornwall. Another member, Dr. Arthur W. Rowe, has advanced a step further in using not only metal brushes but also ordinary brushes for many exquisite preparations of Chalk fossils, and he does not accomplish the work by hand, but by the ingenious apparatus known to dentists as the dental engine.* Finally, the American Museum of Natural History has applied this engine to many uses in the Palæontological workshops, driving it by an electric motor and thus enabling the operator to devote his undivided attention to the fossil which happens to be under treatment.

Many remarkable preparations of fossils contained in calcareous rocks are also being made by the careful use of solvent acids. This process seems to have been first systematically employed about thirty years ago, when the Rev. Norman Glass, improving on the earlier efforts of Prof. R. P. Whitfield and Mr. J. Neilson, applied it to the preparation of the loops and spirals in brachiopod shells. ${ }^{-}$After some preliminary experiments he selected specimens in a state of preservation specially amenable to treatment, and the finest examples of his work may now be seen in the Davidson Collection of Brachiopoda in the British Museum. The fossils being wholly calcareous, Mr. Glass had to prevent corrosion by enveloping the parts in wax as soon as they were bared of matrix. More recently Mr. Walter F. Reid has found that the same object can be more conveniently attained by using weak acid and a protective film of collodion. When the substance of the fossil itself is not calcareous but insoluble in acid, the method of solution is still simpler, and only needs special skill to avoid breaking the delicate residue. Thus Dr. Gerhard Holm has succeeded in removing from the Upper Silurian limestone of Oesel skeletons of Eurypterids which look as if they had been made from a living animal; while both he and Dr. Carl Wiman $\ddagger$ have dissolved out uncrushed Graptolites from the Wenlock Limestone of Gothland, so that they can be studied in every detail and even embedded in paraffin to be cut into sections by the microtome. Siliceous sponges from the Chalk of Hanover have also been similarly treated by Dr. A. Schrammen, and some of his remarkable preparations now exhibited in the British Museum have precisely the aspect of recent skeletons.

* A. W. Rowe, "The Preparation and Mounting of Chalk Fossils," Nat. Science, vol. ix (1866) pp. "303-311.
$\dagger$ T. Davidson, "Monogr. Brit. Foss. Brachiopoda," vol, iv, pp. 270-272 (Palæont.
Soc. I880).

$\ddagger$ C. Wiman, “The Structure of Graptolites," Nat, Science, vol, ix (1896), pp. I86, I87. 
Sections and dissections have always helped materially in the study of fossils; and it was the making of thin sections of fossil wood by William Nicol (of Nicol prism fame), early in the last century, that led to the preparation of transparent rock-sections and the foundation of Petrology as now understood. Laborious dissection has proved very useful in studying the structure of the chambered shells of Cephalopoda, especially of their initial chambers or protoconchs; ${ }^{*}$ and much still remains to be done in this research by those who have the leisure and patience to make careful preparations. The latest and most ingenious application of this method, however, due to Prof. Sollas, $\uparrow$ involves too great an expenditure of time and means for the ordinary amateur. The Oxford Professor has constructed a machine by which a layer of measured thickness can be ground off a fossil. He can thus examine a series of sections taken at regular and definite intervals. Each section is photographed on an enlarged scale, and when the whole fossil has been destroyed by grinding, it is represented by a series of photographs. Plates of wax, of a thickness which can be easily calculated, are then cut into the shape of the several sections recorded by the photographs. These plates are finally superposed one upon another in the exact order of the successive layers they represent, and thus they reproduce on an enlarged scale all the features of the original fossil which are visible in the rock. By this method Prof. Sollas has made a most fundamental contribution to our knowledge of the problematical Devonian fish-like organism, Palcespondylus; while he is now extending his work to the mouth-parts of starfishes and other structures which are difficult to observe in fossils as ordinarily investigated.

In short, in the preparation of fossils for study there is scope for ingenuity to meet each different case; and I will only allude in conclusion to some remarkable examples of Carboniferous Polyzoa shown to me several years ago by one of the keenest Palæontologists of the last generation, the late Dr. John Young, of the Hunterian Museum, Glasgow. Dr. Young discovered that the Polyzoa in question were spinose and thus always adhered to the shaly matrix by their outer face. His method of separating them intact from the rock was to cover their fractured face with a layer of pitch, and then, as soon as it had hardened, to tear this layer off the shale. The pitch pulled the Polyzoa out of the matrix and exposed them perfectly for examination.

Most of those who have prepared fossils with the greatest success have also made their own collections. Indeed, it is essential for more exactitude in the study of Palæontology that

* W. Branco, "Beiträge zur Entwickelungsgeschichte der fossilen Cephalopoden," Palcontogyaphica, vol, xxxi (1879), p. 22 .

+ W. I. Sollas, "A Method for the Investigation of Fossils by Serial Sections," Phil. Trans., Igo3 (No. B.22I). 
the collecting should be done, or at least closely supervised, by those who are actually engaged in research. So many of the problems of life can only be solved when the precise geological age and circumstances of discovery of all the fossils concerned are known, that it is no longer enough to have specimens labelled with the name of a place or a district. Nor is it enough to collect a few choice examples and destroy all the imperfect or abnormal material. I do not agree with those who would enlarge our Museums to preserve the thousands of examples of a species or genus of fossils which happen to have been used for making a generalisation - I think it suffices to keep a small selection; but I am convinced that future progress depends on such exhaustive collecting as that now being done, for example, by Dr. Arthur W. Rowe in his study of the fossils of the English Chalk. Nothing should be destroyed until the research on which it has a bearing has been completed, and then a choice can naturally be made with judgment.

When adequate collections have been formed and studied in the manner just mentioned, we shall be able to distinguish between the changes which organisms have undergone merely by lapse of time, and those which seem to have depended on changes in sediment or depth of water or other conditions. We shall also discover the successive migrations and re-distributions of faunas and floras in accordance with the long series of changes in geograpical features revealed by Geology. This consummation, however, is still far distant, and there is ample scope almost everywhere for members of the Geologists' Association to become pioneers in the requisite research.

So far as the higher vertebrates are concerned, really systematic exploration has already begun to yield astonishing results. It is only necessary to compare Mr. Alfred N. Leeds's collection of Oxfordian reptiles, now in the British Museum, with earlier collections of the same kind, to realise how great is modern progress : and this does not depend so much on better opportunities as on more exact and exhaustive methods in cleaning the bones and observing their natural association in the rock. Even the most fragile specimens can now be extracted by judicious hardening with gelatine and by careful envelopment with plaster or linen bandages - a process which $\mathrm{Mr}$. William Davies was one of the earliest to employ, ${ }^{*}$ and which American collectors have subsequently improved to perfection. Moreover, the exact localities of discoveries even in wild countries are now so carefully noted, that old trails can be resumed without difficulty ; and I know no more striking illustration of this exactitude than that which enabled Mr. Santiago Roth, of the La Plata Museum, to return to a spot in Neuquen, Argentina, and recover the skull

* W. Davies, "On the Preservation of Fossil Mammalian Remains found in Tertiary Deposits," Geol. Mag., vol, il (1865), pp. 239, 240; also ibid, p. 93. 
with a large part of the skeleton of the horned tortoise, Miolania, where he had previously found only a doubtful fragment of the animal.*

The collecting of vertebrate fossils, however, on a large scale, involves so much expenditure that it can rarely be undertaken by a single individual. It is generally done under the auspices of public institutions, which are not only able to obtain funds and the services of experts, but can also overcome difficulties when the rights of landowners have to be considered. The Universities and Museums of North America, especially, have devoted attention to such researches for many years, and made so many remarkable contributions to Palæontology that we are liable to overlook the possibilities and results of similar work elsewhere. The discoveries of Moreno, Ameghino, Roth, Hatcher, E. Nordenskjöld, and others in South America during recent years have been almost equally remarkable. The explorations of Mr. Beadnell, of the Egyptian Geological Survey, and Dr. Andrews, of the British Museum, in the Egyptian desert, have revealed the ancestry of the elephants and added immensely to our knowledge of other mammals of which scarcely any extinct representatives were previously known. The diggings of Grandidier, Forsyth Major, and the missionaries in the swamps and caverns of Madagascar, have yielded unexpected evidence of strange gigantic lemurs and other animals in that country. The expeditions of Prof. E. C. Stirling and Prof. J. W. Gregory have shown how much success awaits systematic bone-digging in Central Australia. Finally, Prof. W. Amalitzky, of the University of Warsaw, has for some years been excavating apparently inexhaustible deposits of reptile-skeletons in the Upper Permian rocks of Northern Russia. Palæontology as now studied, indeed, is no longer dependent on casual quarrying or chance excavating for its best and most satisfactory materials. Collecting is done systematically to solve certain definite problems which are formulated before the work is begun; and amateurs, who are unable to give personal service but happen to be possessed of the financial means, cannot promote Natural Science better than by entrusting funds to some of the public bodies who are actually at work and only need resources to extend their operations.

*F. P. Moreno, "Note on the Discovery of Miolania in Patagonia," Geol. Mag. [4], vol. vi (1899), pp. $3^{85-388 .}$ 